
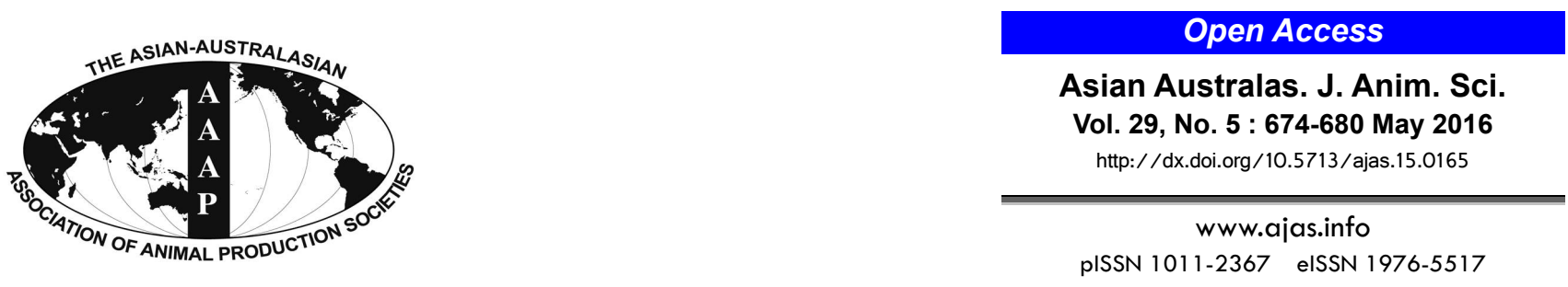

\title{
Toxicity of Mycotoxins from Contaminated Corn with or without Yeast Cell Wall Adsorbent on Broiler Chickens
}

\author{
Q. H. Shang, Z. B. Yang, W. R. Yang, Z. Li, G. G. Zhang, and S. Z. Jiang* \\ Department of Animal Sciences and Technology, Shandong Agricultural University, Tai'an, Shandong 271018, China
}

\begin{abstract}
This study investigated the effects of feeds naturally contaminated with mycotoxins on growth performance, serum biochemical parameters, carcass traits, and splenic heat shock protein 70 (Hsp70) mRNA expression levels in broiler chickens. The efficacy of yeast cell wall (YCW) adsorbent in preventing mycotoxicosis was also evaluated. Three hundred 1-d-old Arbor Acres broiler chicks were randomly allotted to 3 treatments in completely randomized design for $42 \mathrm{~d}$. Each treatment group had 5 replicate pens with 20 birds. The treatments were as follows: i) basal diet (control), ii) naturally contaminated diet (NCD), and iii) $\mathrm{NCD}+0.2 \% \mathrm{YCW}$ adsorbent (NCDD). The NCD decreased average daily gain (ADG) ( $<<0.01)$ of 0 to $21 \mathrm{~d}, 22$ to $42 \mathrm{~d}$, and 0 to $42 \mathrm{~d}$, and increased feed conversion ratio $(p<0.01)$ of 22 to $42 \mathrm{~d}$ and 0 to $42 \mathrm{~d}$. Both the breast meat percentage and thigh meat percentage of the NCD group were significantly higher $(\mathrm{p}<0.01)$ than that of the control group on $\mathrm{d} 21$. The NCD group showed significantly increased levels of triglycerides $(p<0.05)$ and cholesterol $(p<0.05)$ on both d 21 and d 42 compared to the control group. However, the NCD significantly reduced $(p<0.01)$ the high-density lipoprotein (HDL) on $\mathrm{d} 42$ compared to controls. Compared with the NCD, supplementation with YCW significantly improved $(\mathrm{p}<0.01)$ the ADG of 0 to $21 \mathrm{~d}$ and 0 to $42 \mathrm{~d}$, and increased $(\mathrm{p}<0.01)$ concentrations of HDL on $\mathrm{d} 42$, and on d 21, and triglycerides $(\mathrm{p}<0.05)$ on $\mathrm{d} 21$ and d 42. Supplementation with YCW reduced $(\mathrm{p}<0.01)$ the breast meat percentage, the thigh meat percentage, the concentrations of cholesterol $(p<0.01)$ and the low-density lipoprotein $(p<0.05)$ on $d 21$, and improved $(p<0.01)$ the splenic Hsp70 mRNA expression levels compared with the NCD group. The results of this study indicated that feeding NCD for $42 \mathrm{~d}$ had adverse effects on broiler chickens, and that YCW might be beneficial in counteracting the effects of mycotoxins. (Key Words: Broiler, Mycotoxin, Toxicity, Yeast Cell Wall Adsorbent)
\end{abstract}

\section{INTRODUCTION}

Mycotoxins are toxic secondary metabolites of various fungi that ubiquitously exist in cereal crops (Bryden, 2012). Globally, food and feeds have been seriously contaminated with mycotoxins among which aflatoxin (AFL), zearalenone (ZEN), fumonisin (FUM), deoxynivalenol (DON), and ochratoxin A are the most commonly found (Schatzmayr and Streit, 2013). Furthermore, food and feeds are frequently co-contaminated with two or more mycotoxins, and their synergistic interaction may exert additive effects (Che et al., 2011; Schatzmayr and Streit, 2013). The consumption of mycotoxin-contaminated food

\footnotetext{
* Corresponding Author: S. Z. Jiang. Tel: +86-0538-8241257, Fax:+86-0538-8249371, E-mail: shuzhen305@163.com Submitted Mar. 1, 2015; Revised Jun. 6, 2015; Accepted Aug. 29, 2015
}

and feeds leads to reduced nutrient absorption (Maresca et al., 2002), poor growth performance (Chowdhury and Smith, 2004), immunosuppression (Swamy et al., 2003), disturbed reproductive performance (Young et al., 1990), and residues in animal products (Akande et al., 2006), resulting in a massive economic impact worldwide in human health, animal health, and agricultural trade. However, information on the effects of feeds naturally contaminated with mycotoxins on carcass traits and the splenic heat shock protein 70 (Hsp70) mRNA expression levels in broiler chickens is limited.

So far, one of the most practical and effective methods to detoxify mycotoxin-contaminated feed is the use of adsorbents. A polymeric glucomannan mycotoxin adsorbent derived from the cell wall of yeast has been shown to counteract some of the deleterious effects of mycotoxins in swine (Swamy et al., 2002a) and chickens (Aravind et al., 
2003). Because of the extensive use of this adsorbent as a feed additive in China, we carried out this in vivo experiment to evaluate the efficiency of yeast cell wall (YCW) in sequestering mycotoxins and its safety towards broiler chickens.

Therefore, this study was conducted to evaluate the effects of naturally contaminated diets (NCD) on growth performance, serum biochemical parameters, carcass traits, and the splenic Hsp70 mRNA expression levels in broiler chickens, and to determine the efficacy of $\mathrm{YCW}$ in alleviating mycotoxin-induced effects.

\section{MATERIALS AND METHODS}

\section{Adsorbents}

Detoxza, a commercial YCW adsorbent, was obtained from AB Co Products Asia (Harbin, China). The main component of YCW adsorbent used in this study is a kind of highly refined polysaccharide complex with a unique adsorptive capacity.

\section{Experimental animals, diets, and management}

Three hundred 1-d-old Arbor Acres broiler chicks (mixed sexes) were obtained from a local commercial hatchery (Shandong, China). All broiler chicks were individually weighed, wing-banded, and randomly allotted to 3 treatments in completely randomized design. Each treatment group has 5 replicate pens $\left(1.22 \times 1.08 \times 0.45 \mathrm{~m}^{3}\right)$ with 20 birds. The treatments were as follows: i) basal diet (control), ii) NCD with mycotoxins, and iii) $\mathrm{NCD}+0.2 \%$ YCW adsorbent (NCDD). The NCD treatment were formulated by replacing non-contaminated corn that used in the control diet with naturally mycotoxin-contaminated corn, and the NCDD treatment diet was completed by adding adsorbent into the contaminated diets. All diets were prepared in a single batch per treatment group and then stored in covered containers prior to feeding (Table 1). Nutrient concentration of all diets met or exceeded the minimum requirements according to Feeding Standards for Chicken in the People's Republic of China (NY/T 33-2004).

Throughout the experiment, all broiler chickens were kept in an environmentally controlled room with ad libitum feeding and watering. The room temperature was maintained at $32^{\circ} \mathrm{C}$ for the first week, and then reduced $3^{\circ} \mathrm{C}$ weekly until the temperature reached $26^{\circ} \mathrm{C}$. All animals used in this study were cared for strictly following the animal care and use protocol approved by the Animal Nutrition Research Institute of Shandong Agricultural University.

\section{Mycotoxin quantification}

Representative control and the contaminated diets were taken before and at the end of the starter and grower diet periods and analyzed for mycotoxin concentrations by the Asia Mycotoxin Analysis Center (Chaoyang University of Technology, Taichung, Taiwan). DON was analyzed using high-performance liquid chromatography. Fluorometry and enzyme-linked immune-assay were used to measure ZEN, FUM, and AFL concentrations. Mycotoxin concentrations are presented in Table 1. The detection limits for these mycotoxins were $1 \mu \mathrm{g} / \mathrm{kg}$ for AFL, $0.1 \mathrm{mg} / \mathrm{kg}$ for ZEN, 0.1 $\mathrm{mg} / \mathrm{kg}$ for DON (including 3-acetyl deoxynivalenol, 15acetyl deoxynivalenol, and nivalenol), and $0.25 \mathrm{mg} / \mathrm{kg}$ for FUM.

\section{Growth parameters}

Daily mortality was recorded. All broiler chickens were weighed individually each week to determine the average daily gain (ADG). Orts and spillages were collected and weighed daily to determine the average daily feed intake (ADFI). The feed conversion ratio (FCR, $\mathrm{g}$ of $\mathrm{feed} / \mathrm{g}$ of gain) was calculated based on these data at the end of each diet period.

\section{Sample collection}

After fasting for $12 \mathrm{~h}$, ten broilers from each treatment ( 2 per pen) were randomly selected in the morning of $\mathrm{d} 21$ and $\mathrm{d} 42$. Approximately $10 \mathrm{~mL}$ of blood were collected from the jugular vein of each broiler into non-heparinized tubes. After incubated at $37^{\circ} \mathrm{C}$ for $2 \mathrm{~h}$, the serum was separated by centrifugation at $1,500 \times \mathrm{g}$ for $10 \mathrm{~min}$ and stored in $1.5-\mathrm{mL}$ centrifuge tubes at $-20^{\circ} \mathrm{C}$ until biochemical analysis. Broiler chickens were then humanely euthanized by cervical dislocation. Spleen tissues were collected from each broiler chicken and another part was stored at $-80^{\circ} \mathrm{C}$ for $\mathrm{Hsp} 70$ analysis.

\section{Carcass traits}

After blood sampling, the birds were weighed, slaughtered, de-feathered, processed (removal of head and feet), and eviscerated. Then eviscerated yield, breast meat and thigh meat of each broiler chicken were weighed. Eviscerated yield percentage was calculated as a percentage of live body weight. Breast meat percentage and thigh meat percentage were calculated as a percentage of eviscerated yield.

\section{Serum biochemical parameters}

Cholesterol, triglyceride, high-density lipoprotein (HDL), low-density lipoprotein (LDL), and uric acid levels in the serum were determined by a diagnostic kit (Nanjing Jiancheng Bioengineering Institute, Nanjing, China) using an automatic clinical chemistry analyzer (Roche, CobusMira-Plus, Roche Diagnostic System Inc., Los Angeles, CA, USA). 
Table 1. Composition (\%) and dietary mycotoxin concentrations of the experimental diets

\begin{tabular}{|c|c|c|c|c|c|c|}
\hline \multirow{2}{*}{ Item } & \multicolumn{3}{|c|}{ Starter $(0$ to $21 \mathrm{~d})$} & \multicolumn{3}{|c|}{ Grower $(22$ to $42 \mathrm{~d})$} \\
\hline & Control $^{1}$ & $\mathrm{NCD}^{1}$ & $\mathrm{NCDD}^{1}$ & Control & NCD & NCDD \\
\hline \multicolumn{7}{|l|}{ Ingredients } \\
\hline Moldy corn & - & 56.12 & 56.12 & - & 56.25 & 56.25 \\
\hline Normal corn & 56.12 & - & - & 61.25 & 5.00 & 5.00 \\
\hline Soybean meal & 32.50 & 32.50 & 32.50 & 26.00 & 26.00 & 26.00 \\
\hline Corn gluten meal & 4.50 & 4.50 & 4.50 & 5.00 & 5.00 & 5.00 \\
\hline Soybean oil & 2.00 & 2.00 & 2.00 & 3.00 & 3.00 & 3.00 \\
\hline Calcium hydrogen phosphate & 1.60 & 1.60 & 1.60 & 1.50 & 1.50 & 1.50 \\
\hline Limestone & 1.30 & 1.30 & 1.30 & 1.40 & 1.40 & 1.40 \\
\hline Sodium chloride & 0.30 & 0.30 & 0.30 & 0.30 & 0.30 & 0.30 \\
\hline Lysine & 0.24 & 0.24 & 0.24 & 0.15 & 0.15 & 0.15 \\
\hline Methionine & 0.24 & 0.24 & 0.24 & 0.20 & 0.20 & 0.20 \\
\hline Vitamin-mineral premix ${ }^{2}$ & 1.00 & 1.00 & 1.00 & 1.00 & 1.00 & 1.00 \\
\hline Sand & 0.20 & 0.20 & - & 0.20 & 0.20 & - \\
\hline Yeast cell wall adsorbent & - & - & 0.20 & - & - & 0.20 \\
\hline \multicolumn{7}{|l|}{ Calculated composition } \\
\hline Metabolizable energy $(\mathrm{MJ} / \mathrm{kg})$ & 12.64 & 12.64 & 12.64 & 13.01 & 13.01 & 13.01 \\
\hline Crude protein $(\%)$ & 21.36 & 21.36 & 21.36 & 19.35 & 19.35 & 19.35 \\
\hline Calcium $(\%)$ & 0.96 & 0.96 & 0.96 & 0.95 & 0.95 & 0.95 \\
\hline Total phosphorus (\%) & 0.66 & 0.66 & 0.66 & 0.63 & 0.63 & 0.63 \\
\hline Sodium chloride $(\%)$ & 0.30 & 0.30 & 0.30 & 0.30 & 0.30 & 0.30 \\
\hline Lysine $(\%)$ & 1.20 & 1.20 & 1.20 & 1.00 & 1.00 & 1.00 \\
\hline Methionine (\%) & 0.54 & 0.54 & 0.54 & 0.48 & 0.48 & 0.48 \\
\hline Total sulfur amino acids (\%) & 0.88 & 0.88 & 0.88 & 0.79 & 0.79 & 0.79 \\
\hline Threonine (\%) & 0.81 & 0.81 & 0.81 & 0.73 & 0.73 & 0.73 \\
\hline Tryptophan (\%) & 0.26 & 0.26 & 0.26 & 0.23 & 0.23 & 0.23 \\
\hline \multicolumn{7}{|l|}{ Analyzed mycotoxins $(\mu \mathrm{g} / \mathrm{kg})$} \\
\hline Aflatoxin $\mathrm{B}_{1}$ & 6.68 & 102.08 & 102.08 & 8.48 & 101.18 & 101.18 \\
\hline Zearalenone & 18.32 & 281.92 & 281.92 & 18.81 & 285.20 & 285.20 \\
\hline Fumonisin & 952.59 & $5,874.38$ & $5,874.38$ & $1,276.88$ & $5,977.36$ & $5,977.36$ \\
\hline Deoxynivalenol & 642.16 & $2,038.96$ & $2,038.96$ & 545.73 & $2,051.08$ & $2,051.08$ \\
\hline
\end{tabular}

${ }^{1}$ Control, basal diet; $\mathrm{NCD}$, naturally contaminated diet; $\mathrm{NCDD}, \mathrm{NCD}+0.2 \%$ yeast cell wall adsorbent.

${ }^{2}$ Supplied per kilogram of diet: vitamin A, 8,050 IU; cholecalciferol, 1,800 IU; vitamin E, $20 \mathrm{IU}$; vitamin $\mathrm{K}_{3}, 5.1 \mathrm{mg}$; thiamin, $2.4 \mathrm{mg}$; riboflavin, $8.2 \mathrm{mg}$; pantothenic acid, $15.3 \mathrm{mg}$; pyridoxine, $3.1 \mathrm{mg}$; cobalamin, $0.02 \mathrm{mg}$; niacin, $32 \mathrm{mg}$; choline chloride, $1,000 \mathrm{mg}$; biotin, $0.20 \mathrm{mg}$; folic acid, $1.2 \mathrm{mg}$; Mn, $68 \mathrm{mg}$; Fe, $85 \mathrm{mg}$; Zn, $58 \mathrm{mg}$; Cu, $8.6 \mathrm{mg}$; I, $0.27 \mathrm{mg}$; Se, $0.20 \mathrm{mg}$.

Determination of spleen Hsp70 mRNA expression levels by real-time polymerase chain reaction

Total RNA was extracted from splenocytes using an ultra pure RNA extraction kit (Cat\#CW0581, CWbio. Co. Ltd., Beijing, China). The RNA concentrations and integrity were determined by agarose gel electrophoresis using $5 \mu \mathrm{L}$ samples. The DNAse treated RNA was used for cDNA synthesis using a HiFi-MMLV cDNA First Strand Synthesis kit (Cat\#CW0744, CWbio. Co. Ltd., China) with random primers and stored at $-80^{\circ} \mathrm{C}$. The real-time polymerase chain reaction (RT-PCR) reactions were performed by an RT-PCR system (Roche 480, Roche Diagnostic System Inc., Los Angeles, CA, USA) using UltraSYBR Mixture, ROX (Cat\#CW0956, CWbio. Co. Ltd., China). After denaturing at $95^{\circ} \mathrm{C}$ for $10 \mathrm{~min}$, the PCR amplification was performed for 40 cycles $\left(95^{\circ} \mathrm{C}\right.$ for $15 \mathrm{~s}$ and $60^{\circ} \mathrm{C}$ for $\left.1 \mathrm{~min}\right)$, followed by a final extension step $\left(72^{\circ} \mathrm{C}\right.$ for $\left.10 \mathrm{~min}\right)$. The splenic Hsp70 mRNA expression levels were normalized with the relative intensity of the $\beta$-actin gene. The sequences of oligonucleotide primers used in RT-PCR analysis are presented in Table 2 .

\section{Statistical analysis}

Data were analyzed as a completely randomized design using the GLM procedure of SAS (Version 9.0; SAS Inst. Inc., Cary NC, USA). The pen was used as the experimental unit. The data were analyzed as a completely randomized design to examine the overall effect of treatments. Differences among treatments were separated using Duncan's multiple range test and accepted as significant if $\mathrm{p}<0.05$. 
Table 2. Sequences of oligonucleotide primers used in real-time PCR analysis

\begin{tabular}{|c|c|c|c|}
\hline Gene & & Oligonucleotide sequences ( $5^{\prime}$ to $\left.3^{\prime}\right)$ & Accession number \\
\hline \multirow[t]{2}{*}{ Hsp70 } & $\mathrm{F}$ & GACAAGTCAAAGCCGCACAT & NM_001006685 \\
\hline & $\mathrm{R}$ & AAGTCGTTCATCGGGAGC & \\
\hline \multirow[t]{2}{*}{$\beta$-actin } & $\mathrm{F}$ & CAACACAGTGCTGTCTGGTGG & NM_205518 \\
\hline & $\mathrm{R}$ & ATCGTACTCCTGCTTGCTGAT & \\
\hline
\end{tabular}

PCR, polymerase chain reaction; Hsp70, Heat shock protein 70; F, forward primer; R, reverse primer.

\section{RESULTS}

\section{Growth performance}

The ADFI did not differ significantly among treatments during the starter or grower diet period (Table 3). However, compared with the control, the NCD decreased ADG $(\mathrm{p}<0.01)$ of 0 to $21 \mathrm{~d}, 22$ to $42 \mathrm{~d}$, and 0 to $42 \mathrm{~d}$, and increased FCR $(p<0.01)$ of 22 to $42 \mathrm{~d}$ and 0 to $42 \mathrm{~d}$. Supplementation with YCW significantly improved $(\mathrm{p}<0.01)$ the ADG of 0 to $21 \mathrm{~d}$ and 0 to $42 \mathrm{~d}$ compared with the NCD. The mortalities of chickens fed the NCD were higher $(\mathrm{p}<0.05)$ compared with the control. But mortality was reduced $(p<0.05)$ significantly by adding YCW in basal diets.

\section{Carcass traits}

Both the breast meat percentage and thigh meat percentage of the NCD group were significantly higher $(\mathrm{p}<0.01)$ than that of the control group on $\mathrm{d} 21$, but not on $\mathrm{d}$ 42 (Table 4). All broiler chickens had similar eviscerated yield percentage during the entire experimental period.
Supplementation with YCW reduced $(p<0.01)$ the effect of mycotoxins on the breast meat percentage and thigh meat percentage on d 21 compared to the NCD.

\section{Serum biochemical parameters}

The NCD group showed significantly increased levels of triglycerides $(\mathrm{p}<0.05)$ and cholesterol $(\mathrm{p}<0.05)$ on both $d$ 21 and d 42 compared to the control group (Table 5). However, the NCD significantly reduced $(p<0.01)$ the HDL on d 42 compared to controls. No differences were noted in uric acid among treatments. Supplementation of YCW at the dosage of $0.2 \%$ to the NCD increased $(p<0.01)$ concentrations of HDL on $\mathrm{d} 42$, and decreased concentrations of cholesterol $(p<0.01)$ and the LDL $(\mathrm{p}<0.05)$ on $\mathrm{d} 21$, and triglycerides $(\mathrm{p}<0.05)$ on $\mathrm{d} 21$ and $\mathrm{d}$ 42.

\section{Splenic Hsp70 mRNA expression levels}

The splenic Hsp70 mRNA expression levels of control, NCD, and NCDD groups on d 42 are presented in Figure 1. The NCD group showed significantly higher $(\mathrm{p}<0.01)$

Table 3. The effects of basal diet and naturally mycotoxin-contaminated diets with or without yeast cell wall adsorbent, on growth performance of broiler chickens $(n=5)$

\begin{tabular}{|c|c|c|c|c|c|}
\hline Item & Control $^{1}$ & $\mathrm{NCD}^{1}$ & $\mathrm{NCDD}^{1}$ & SEM & p-value \\
\hline \multicolumn{6}{|l|}{ BW (g) } \\
\hline $0 \mathrm{~d}$ & 50.34 & 52.03 & 52.55 & 2.06 & 0.735 \\
\hline $21 \mathrm{~d}$ & $798.99^{\mathrm{a}}$ & $740.83^{\mathrm{c}}$ & $772.85^{b}$ & 7.345 & $<0.001$ \\
\hline $42 \mathrm{~d}$ & $2,296.50^{\mathrm{a}}$ & $2,117.59^{\mathrm{b}}$ & $2,184.47^{\mathrm{ab}}$ & 42.868 & 0.036 \\
\hline \multicolumn{6}{|l|}{$\operatorname{ADG}(\mathrm{g} / \mathrm{d})$} \\
\hline 0 to $21 \mathrm{~d}$ & $35.65^{\mathrm{a}}$ & $32.80^{\mathrm{c}}$ & $34.30^{\mathrm{b}}$ & 0.433 & 0.002 \\
\hline 22 to $42 \mathrm{~d}$ & $71.30^{\mathrm{a}}$ & $65.56^{\mathrm{b}}$ & $67.23^{\mathrm{b}}$ & 1.046 & 0.006 \\
\hline 0 to $42 \mathrm{~d}$ & $53.48^{\mathrm{a}}$ & $49.18^{c}$ & $50.76^{\mathrm{b}}$ & 0.413 & 0.001 \\
\hline \multicolumn{6}{|l|}{ ADFI (g/d) } \\
\hline 0 to $21 \mathrm{~d}$ & 47.72 & 46.6 & 47.23 & 0.502 & 0.324 \\
\hline 22 to $42 \mathrm{~d}$ & 133.6 & 133.52 & 134.58 & 0.787 & 0.588 \\
\hline 0 to $42 \mathrm{~d}$ & 90.66 & 90.06 & 90.90 & 0.540 & 0.543 \\
\hline \multicolumn{6}{|l|}{ FCR } \\
\hline 0 to $21 \mathrm{~d}$ & $1.34^{\mathrm{b}}$ & $1.42^{\mathrm{a}}$ & $1.38^{\mathrm{ab}}$ & 0.023 & 0.075 \\
\hline 22 to $42 \mathrm{~d}$ & $1.88^{\mathrm{b}}$ & $2.04^{\mathrm{a}}$ & $2.00^{\mathrm{a}}$ & 0.026 & 0.003 \\
\hline 0 to $42 \mathrm{~d}$ & $1.70^{\mathrm{b}}$ & $1.83^{\mathrm{a}}$ & $1.79^{\mathrm{a}}$ & 0.015 & $<0.001$ \\
\hline \multicolumn{6}{|l|}{ Mortality (\%) } \\
\hline 0 to $42 \mathrm{~d}$ & $1.00^{\mathrm{b}}$ & $6.00^{\mathrm{a}}$ & $1.00^{\mathrm{b}}$ & 1.350 & 0.034 \\
\hline
\end{tabular}

SEM, standard error of the mean; BW, body weight; ADG, average daily gain; ADFI, average daily feed intake; FCR, $g$ of feed/g of gain.

${ }^{1}$ Control, basal diet; NCD, naturally contaminated diet; NCDD, NCD $+0.2 \%$ yeast cell wall adsorbent.

${ }^{\mathrm{a}, \mathrm{b}}$ Means within a row with different letters differ significantly at $\mathrm{p}<0.05$. 
Table 4. The effects of basal diet and naturally mycotoxin-contaminated diets with or without yeast cell wall adsorbent, on carcass rates of broiler chickens $(\mathrm{n}=5)$

\begin{tabular}{|c|c|c|c|c|c|}
\hline Item & Control $^{1}$ & $\mathrm{NCD}^{1}$ & $\mathrm{NCDD}^{1}$ & SEM & p-value \\
\hline \multicolumn{6}{|c|}{ Breast meat percentage (\%) } \\
\hline $21 \mathrm{~d}$ & $61.56^{\mathrm{b}}$ & $64.42^{\mathrm{a}}$ & $58.48^{\mathrm{b}}$ & 0.315 & 0.004 \\
\hline $42 \mathrm{~d}$ & 83.47 & 85.97 & 83.45 & 0.290 & 0.219 \\
\hline \multicolumn{6}{|c|}{ Thigh meat percentage $(\%)$} \\
\hline $21 \mathrm{~d}$ & $62.65^{\mathrm{b}}$ & $67.89^{\mathrm{a}}$ & $63.38^{\mathrm{b}}$ & 0.233 & 0.001 \\
\hline $42 \mathrm{~d}$ & 71.11 & 71.95 & 70.46 & 0.348 & 0.568 \\
\hline \multicolumn{6}{|c|}{ Eviscerated yield percentage (\%) } \\
\hline $21 \mathrm{~d}$ & 708.58 & 706.12 & 707.76 & 1.996 & 0.315 \\
\hline $42 \mathrm{~d}$ & 764.30 & 755.32 & 760.74 & 1.356 & 0.616 \\
\hline
\end{tabular}

SEM, Standard error of the mean.

${ }^{1}$ Control, basal diet; NCD, naturally contaminated diet; NCDD, NCD $+0.2 \%$ yeast cell wall adsorbent.

${ }^{\mathrm{a}, \mathrm{b}}$ Means within a row with different letters differ significantly at $\mathrm{p}<0.05$.

Hsp70 mRNA expression levels than that of the control group. Supplementation with YCW improved $(\mathrm{p}<0.01)$ the splenic Hsp70 mRNA expression levels compared with the NCD group.

\section{DISCUSSION}

Although each ingredient had been carefully selected, the AFL, ZEN, FUM, and DON were detected in the basal diet, which may suggest that chicken feeds are extensively contaminated with mycotoxins in China. However, the levels of AFL, ZEN, FUM, and DON were considered acceptable, since they were in compliance with the regulations of the Food and Agriculture Organization of the

Table 5. The effects of basal diet and naturally mycotoxincontaminated diets with or without yeast cell wall adsorbent, on serum biochemical parameters of broiler chickens $(n=5)$

\begin{tabular}{|c|c|c|c|c|c|}
\hline Item & Control $^{1}$ & $\mathrm{NCD}^{1}$ & $\mathrm{NCDD}^{1}$ & SEM & p-value \\
\hline \multicolumn{6}{|c|}{ Cholesterol (mmol/L) } \\
\hline $21 \mathrm{~d}$ & $3.06^{\mathrm{b}}$ & $3.22^{\mathrm{a}}$ & $3.09^{\mathrm{b}}$ & 0.79 & 0.001 \\
\hline $42 \mathrm{~d}$ & $3.05^{\mathrm{b}}$ & $3.13^{\mathrm{a}}$ & $3.10^{\mathrm{a}}$ & 1.061 & 0.019 \\
\hline \multicolumn{6}{|c|}{ Triglycerides (mmol/L) } \\
\hline $21 \mathrm{~d}$ & $0.42^{\mathrm{b}}$ & $0.87^{\mathrm{a}}$ & $0.54^{\mathrm{b}}$ & 0.248 & 0.017 \\
\hline $42 \mathrm{~d}$ & $0.88^{\mathrm{b}}$ & $1.03^{\mathrm{a}}$ & $0.68^{\mathrm{c}}$ & 1.19 & 0.038 \\
\hline \multicolumn{6}{|c|}{$\mathrm{HDL}(\mathrm{mmol} / \mathrm{L})$} \\
\hline $21 \mathrm{~d}$ & 1.68 & 1.82 & 1.47 & 0.356 & 0.098 \\
\hline $42 \mathrm{~d}$ & $1.60^{\mathrm{a}}$ & $1.43^{\mathrm{b}}$ & $1.59^{\mathrm{a}}$ & 0.018 & 0.001 \\
\hline \multicolumn{6}{|c|}{$\mathrm{LDL}(\mathrm{mmol} / \mathrm{L})$} \\
\hline $21 \mathrm{~d}$ & $1.18^{\mathrm{a}}$ & $1.21^{\mathrm{a}}$ & $1.04^{\mathrm{b}}$ & 0.564 & 0.036 \\
\hline $42 \mathrm{~d}$ & 0.87 & 0.95 & 0.86 & 2.01 & 0.235 \\
\hline \multicolumn{6}{|c|}{ Uric acid $(\mathrm{mmol} / \mathrm{L})$} \\
\hline $21 \mathrm{~d}$ & 1.03 & 1.05 & 1.01 & 0.674 & 0.063 \\
\hline $42 \mathrm{~d}$ & 0.50 & 0.42 & 0.46 & 1.039 & 0.217 \\
\hline
\end{tabular}

SEM, standard error of the mean; HDL, high-density lipoprotein; LDL, low-density lipoprotein.

1 Control, basal diet; NCD, naturally contaminated diet; NCDD, $\mathrm{NCD}+0.2 \%$ yeast cell wall adsorbent.

a,b Means within a row with different letters differ significantly at $\mathrm{p}<0.05$.
United Nations (FAO, 2006; AFL, $20 \mu \mathrm{g} / \mathrm{kg}$; ZEN, $1 \mathrm{mg} / \mathrm{kg}$; FUM, $3 \mathrm{mg} / \mathrm{kg}$; and DON, $2 \mathrm{mg} / \mathrm{kg}$ ).

The common symptom of mycotoxins in poultry is poor growth performance (Chowdhury and Smith, 2004), which results in massive economic losses. The effect of mycotoxins on growth performance of broiler chickens was contradictory. In the current study, ADG of broilers in NCD was significantly reduced and the mortalities of chickens fed the NCD were higher compared to those provided the basal diet, but without any changes in ADFI. These results indicated that the adverse effect of mycotoxins on ADG was probably due to impairment of nutrient absorption and inhibition of protein synthesis (Klasing and Barnes, 1988), other than the attenuation of feed intake. Xu et al. (2011) also observed that body weight gain reduced with

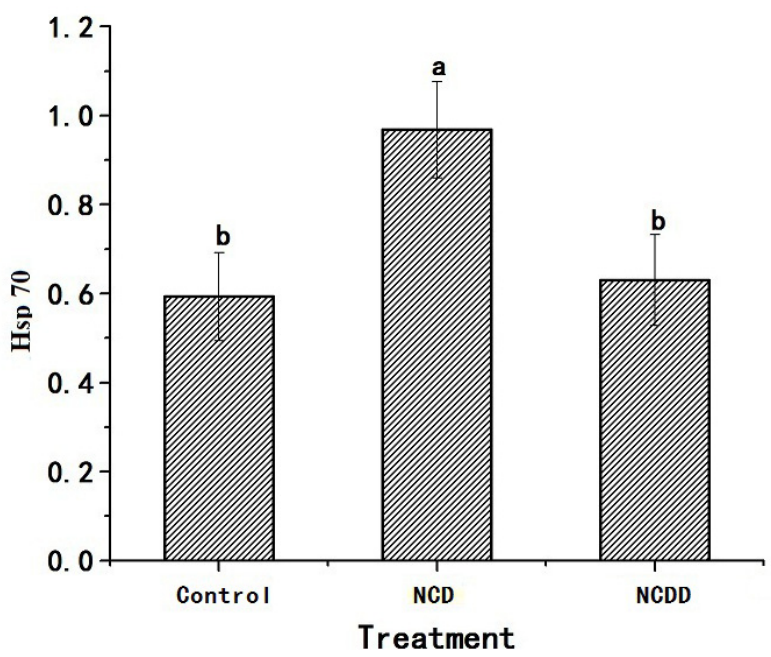

Figure 1. Splenic heat shock protein 70 (Hsp70) mRNA expression levels of 42-d broiler chickens that provided basal diet and naturally mycotoxin-contaminated diets with or without yeast cell wall adsorbent $(\mathrm{p}<0.01, \mathrm{SEM}=0.054)$. Values are the mean \pm SEM $(n=5)$. NCD, naturally contaminated diet; NCDD, $\mathrm{NCD}+0.2 \%$ yeast cell wall adsorbent. SEM, standard error of the mean. Bars with different letters differ significantly at $\mathrm{p}<0.05$. 
increasing concentrations of dietary DON without affecting the overall feed consumption of broilers as the mucosal lining of the gastrointestinal tract was altered. In contrast, Awad et al. (2006) indicated that body weight, body weight gain, and feed conversion were not affected by the inclusion of $5 \mathrm{mg} / \mathrm{kg}$ of DON in the feed. It has been reported that synergistic effects among mycotoxins can multiply their individual adverse effects (Conkova et al., 2003). Therefore, this inconsistency of results may be due to the presence of other mycotoxins and their synergistic effect in the liver, which therefore inhibited protein and DNA syntheses (Huff et al., 1988).

Very limited information is available on the effect of feeding mycotoxin-contaminated grains on carcass traits of broilers. In the present study, the beast meat percentage and thigh meat percentage of the NCD group were significantly higher than that of the control group on $\mathrm{d} 21$, without significantly changes in eviscerated yield percentage, breast meat percentage and thigh meat percentage on $\mathrm{d} 42$. This may be because Zearalanol promotes protein synthesis and increases the lean meat ratio in a manner similar to estrogen (Wang, 2013). However, its mechanisms still need further research.

Changes in serum biochemical parameters can be used to predict toxic effects of aflatoxicosis before the appearance of major symptoms (Kececi et al., 1998). In this study, the NCD resulted in an increase in triglycerides and cholesterol, and a decrease in the concentration of HDL as compared to the control diet. Hedayati et al. (2014) have reported that cholesterol level has been increased significantly by addition of AFL into the diet. Chowdhury and Smith (2007) also observed plasma cholesterol concentration increased compared with controls when birds were fed contaminated grains. Increased cholesterol levels may be attributed to the hepatotoxic effects of AFL, ZEN, FUM, and DON or their synergetic effect that characterized by impairment of transport and lipid metabolism of liver (Rosa et al., 2001). The HDL can remove cholesterol from the blood vessels and carries it back to the liver, where it can be processed and sent out of the body. The liver is an important place for synthesis of HDL. The reduced HDL may suggest that mycotoxins exert a toxic effect on liver of the chickens.

One of the key cellular responses to toxicant exposure, which could potentially be used as early marker of toxicity, is the heat shock response (Carnevali and Maradonna, 2003). The Hsp70 is closely related to cytoprotection and induced in response to toxic stress (Hassen et al., 2007). In this study, the results clearly indicated that mycotoxins induced an increase in the splenic Hsp70 mRNA expression levels. Previous reported studies also showed significant changes in the expression levels of Hsp 70 mRNA in different cell lines (El Golli et al., 2006) that may be due to systemic inflammation, oxidative stress (Hassen et al., 2007), or tissue damage caused by mycotoxins.

A variety of adsorbents that prevent mycotoxicosis have been extensively studied in livestock (Huwig et al., 2001). It has been shown that glucomannan polymer was efficacious in preventing some adverse effects of Fusarium mycotoxins in broiler chickens (Swamy et al., 2002b), swine (Swamy et al., 2003), and laying hens (Chowdhury and Smith, 2004). Yeast $\beta$-D-glucan has been also shown to be a suppressor of mycotoxin effects (Yiannikouris et al., 2004) because it has a large surface area and high adsorption capacity. In the current study, the improved results of ADG on 0 to $42 \mathrm{~d}$, cholesterol on $\mathrm{d} 21$, triglycerides in serum on both d 21 and d 42, HDL in serum on $\mathrm{d} 42$ and the splenic Hsp70 mRNA expression levels on d 42 in NCDD group compared to NCD group may due to YCW partially trapping the mycotoxin molecule in its glucomannan matrix and preventing toxin absorption from the gastrointestinal tract (Che et al., 2011). Li et al. (2012) reported that supplementation of YCW to the NCD showed a positive effect against oxidative stress (total superoxide dismutase, malondialdehyde in serum) and on immunological parameters (splenic mRNA expression of interleukin1-1 $\beta$ and interleukin-6). Therefore, the YCW could potentially be an effective method to adsorb and sequester mycotoxins, leading to the reduction of toxin bioavailability (Kogan and Kocher, 2007).

In summary, this study showed that diets naturally contaminated with mycotoxins negatively affected growth performance, carcass traits, and some serum biochemical parameters. The YCW that added to NCD prevented some adverse effects of mycotoxins on broiler chickens. These results suggested that YCW might be beneficial in counteracting the effects of mycotoxins. However, further research is required to evaluate the addition of $\mathrm{YCW}$ in feeds at different concentrations, in order to define the optimum application rate for the reduction of mycotoxin effects.

\section{CONFLICT OF INTEREST}

We certify that there is no conflict of interest with any financial organization regarding the material discussed in the manuscript.

\section{REFERENCES}

Akande, K. E., M. M. Abubakar, T. A. Adegbola, and S. E. Bogoro. 2006. Nutritional and health implications of mycotoxins in animal feeds: A review. Pakistan J. Nutr. 5:398-403.

Aravind, K. L., V. S. Patil, G. Devegowda, B. Umakantha, and S. P. Ganpule. 2003. Efficacy of esterified glucomannan to counteract mycotoxicosis in naturally contaminated feed on performance and serum biochemical and hematological 
parameters in broilers. Poult. Sci. 82:571-576.

Awad, W. A., J. Bohm, E. Razzazi-Fazeli, and J. Zentek. 2006. Effects of feeding deoxynivalenol contaminated wheat on growth performance, organ weights and histological parameters of the intestine of broiler chickens. J. Anim. Physiol. Anim. Nutr. 90:32-37.

Bryden, W. L. 2012. Mycotoxin contamination of the feed supply chain: Implications for animal productivity and feed security. Anim. Feed. Sci. Technol. 173:134-158.

Carnevali, O. and F. Maradonna. 2003. Exposure to xenobiotic compounds: Looking for new biomarkers. Gen. Comp. Endocrinol. 131:203-208.

Che, Z., Y. Liu, H. Wang, H. Zhu, Y. Hou, and B. Ding. 2011. The protective effects of different mycotoxin adsorbents against blood and liver pathological changes induced by moldcontaminated feed in broilers. Asian Australas. J. Anim. Sci. 24:250-257.

Chowdhury, S. R. and T. K. Smith. 2004. Effects of feeding blends of grains naturally contaminated with Fusarium mycotoxins on performance and metabolism of laying hens. Poult. Sci. 83:1849-1856.

Chowdhury, S. R. and T. K. Smith. 2007. Effects of feed-borne Fusarium mycotoxins on performance, plasma chemistry and hepatic fractional protein synthesis rates of turkeys. Can. J. Anim. Sci. 87:543-551.

Conkova, E., A. Laciakova, G. Kovac, and H. Seidel. 2003. Fusarial toxins and their role in animal diseases. Vet. J. 165: 214-220.

El Golli, E., W. Hassen, A. Bouslimi, C. Bouaziz, M. M. Ladjimi, and H. Bacha. 2006. Induction of Hsp 70 in Vero cells in response to mycotoxins: Cytoprotection by sub-lethal heat shock and by Vitamin E. Toxicol. Lett. 166:122-130.

Food and Agriculture Organization of the United Nations (FAO). 2006. Worldwide regulations for mycotoxins in food and feed in 2003. FAO Food and Nutrition Paper No. 81. Rome, Italy.

Hassen, W., I. Ayed-Boussema, A. A. Oscoz, A. De Cerain Lopez, and H. Bacha. 2007. The role of oxidative stress in zearalenone-mediated toxicity in Hep G2 cells: Oxidative DNA damage, gluthatione depletion and stress proteins induction. Toxicology 232:294-302.

Hedayati, M., M. Manafi, M. Yari, and S. V. Mousavipour. 2014. Commercial broilers exposed to aflatoxin $b_{1}$ : Efficacy of a commercial mycotoxin binder on internal organ weights, biochemical traits and mortality. Int. J. Agric. For. 4:351-358.

Huff, W. E., R. B. Harvey, L. F. Kubena, and G. E. Rottinghaus. 1988. Toxic synergism between aflatoxin and t-2 toxin in broiler chickens. Poult. Sci. 67:1418-1423.

Huwig, A., S. Freimund, O. Kappeli, and H. Dutler. 2001. Mycotoxin detoxication of animal feed by different adsorbents. Toxicol. Lett. 122:179-188.

Kececi, T., H. Oguz, V. Kurtoglu, and O. Demet. 1998. Effects of polyvinylpolypyrrolidone, synthetic zeolite and bentonite on serum biochemical and haematological characters of broiler chickens during aflatoxicosis. Br. Poult. Sci. 39:452-458.

Klasing, K. C. and D. M. Barnes. 1988. Decreased amino acid requirements of growing chicks due to immunologic stress. J. Nutr. 118:1158-1164.
Kogan, G. and A. Kocher. 2007. Role of yeast cell wall polysaccharides in pig nutrition and health protection. Livest. Sci. 109:161-165.

Li, Z., Z. B. Yang, W. R. Yang, S. J. Wang, S. Z. Jiang, and Y. B. Wu. 2012. Effects of feed-borne Fusarium mycotoxins with or without yeast cell wall adsorbent on organ weight, serum biochemistry, and immunological parameters of broiler chickens. Poult. Sci. 91:2487-2495.

Maresca, M., R. Mahfoud, N. Garmy, and J. Fantini. 2002. The mycotoxin deoxynivalenol affects nutrient absorption in human intestinal epithelial cells. J. Nutr. 132:2723-2731.

Ministry of Agriculture of China. 2004. Feeding standard of Chicken of the People's Republic of China. NY/T 33-2004. Ministry of Agriculture, Beijing, China.

Rosa, C. A. R., R. Miazzo, C. Magnoli, M. Salvano, S. M. Chiacchiera, S. Ferrero, M. Saenz, E. C. Q. Carvalho, and A. Dalcero. 2001. Evaluation of the efficacy of bentonite from the south of Argentina to ameliorate the toxic effects of aflatoxin in broilers. Poult. Sci. 80:139-144.

Schatzmayr, G. and E. Streit. 2013. Global occurrence of mycotoxins in the food and feed chain: Facts and figures. World Mycotoxin J. 6:213-222.

Swamy, H. V. L. N., T. K. Smith, E. J. MacDonald, N. A. Karrow, B. Woodward, and H. J. Boermans. 2003. Effects of feeding a blend of grains naturally contaminated with Fusarium mycotoxins on growth and immunological measurements of starter pigs, and the efficacy of a polymeric glucomannan mycotoxin adsorbent. J. Anim. Sci. 81:2792-2803.

Swamy, H. V., T. K. Smith, E. J. MacDonald, H. J. Boermans, and E. J. Squires. 2002a. Effects of feeding a blend of grains naturally contaminated with Fusarium mycotoxins on swine performance, brain regional neurochemistry, and serum chemistry and the efficacy of a polymeric glucomannan mycotoxin adsorbent. J. Anim. Sci. 80:3257-3267.

Swamy, H. V., T. K. Smith, P. F. Cotter, H. J. Boermans, and A. E. Sefton. 2002b. Effects of feeding blends of grains naturally contaminated with Fusarium mycotoxins on production and metabolism in broilers. Poult. Sci. 81:966-975.

Wang, W. 2013. Phytoestrogen $\alpha$-Zearalanol in an Animal Model of Menopause. In: Nutrition and Diet in Menopause (Eds. C. H. Martin, R. R. Watson, and V. R. Preedy). Humana Press, New York, NY, USA. pp. 407-417.

Xu, L., S. D. Eicher, and T. J. Applegate. 2011. Effects of increasing dietary concentrations of corn naturally contaminated with deoxynivalenol on broiler and turkey poult performance and response to lipopolysaccharide. Poult. Sci. 90:2766-2774.

Yiannikouris, A., J. Francois, L. Poughon, C. G. Dussap, G. Bertin, G. Jeminet, and J. P. Jouany. 2004. Alkali extraction of $\beta$-Dglucans from Saccharomyces cerevisiae cell wall and study of their adsorptive properties toward zearalenone. J. Agric. Food Chem. 52:3666-3673.

Young, L. G., H. Ping, and G. J. King. 1990. Effects of feeding zearalenone to sows on rebreeding and pregnancy. J. Anim. Sci. 68:15-20. 